\title{
AVP Gene Product
}

National Cancer Institute

\section{Source}

National Cancer Institute. AVP Gene Product. NCI Thesaurus. Code C131899.

A protein encoded by the AVP gene. 